\title{
Exercise Method of Hockey Basic Technique Skills
}

\author{
$1^{\text {st }}$ Much. Samsul Huda \\ Universitas Mulawaraman \\ Samarinda, Indonesia
}

\author{
$2^{\text {nd }}$ Janje J Sapulete \\ Universitas Mulawaraman \\ Samarinda, Indonesia
}

\author{
$3^{\text {rd }}$ Zulfikar \\ Universitas Negeri Jakarta \\ Jakarta, Indonesia
}

\begin{abstract}
In this research, 20 from 54 the cluster of the student is random sampling. The research was focused on three aspect; training method and motivation achievement to the ability of the basic techniques of hockey students. The data were collected with questionnaire and analyzed with tuckey analysis. Result on the analysis it is concluded that (1) the ability of the basic techniques of hockey students who are given the tactical training method is higher than students who were given drill training method.
\end{abstract} method

Keywords - ability of the basic techniques of hockey, training

\section{INTRODUCTION}

Game hockey is one of the sports that was built in SMAN 3 Samarinda incorporated in extracurricular. The hockey team that fostered it has a poor performance in every competition that followed. Though in the coaching is trained by a tactical trainer brought from Mulawarman University which is credibility in hockey sports is no doubt with the intensity of exercise three times a week. To get a good and reliable player requires a player who has a good level of basic engineering skills and good physical condition as well, because the mastery of good basic techniques will greatly influence in a game.

Basic techniques that need to be mastered by a hockey player include passing, stoping, dribling, and shooting. From the field writer's observation of hockey team SMAN 3 samarinda it is found that, in a team match is often experienced failure in the attack, it is caused less accurate mastery the ball caused by driblling techniques that are controlled less, whereas driblllig is one of the success of someone support hockey player in game proofing. When biomechanically analyzed errors in dribbling may be too stiff hand holding a stick so that the wrist round is less relaxed or the ball position with the stick too far so the ball becomes wild and hard to control, or maybe errors in other body positions. To be able to correct the errors that occur it needs to be fixed basic techniques than the dribbling itself, and it can not be separated also the role of trainers in using the technique training methods in the exercise.

\section{A. Skill of Hockey Technique}

Dribbling is a skill in the motor domain and is often referred to as motor skills. Such motor skills can be distinguished by fine motor skills and gross motor skills. Magill says that "motor skills can be categorized with rough skills and refined skills. It further states that: sport skills almost entirely use rough skill" [10]. Skills can be classified with open skills and closed skills. Furthermore it is said that closed skill is a skill that is not influenced by the surrounding environment, whereas open skill is skill which is enjoined by the surrounding environment [9]. To be able to master the basic technical skills of hockey skills is not independent of the role of motor learning ever done before. Motor learning itself is "aset of processes related to practice or experience that lead to permanent change in skilled behavior. There are three stages in motor learning that are: 1) cognitive stages, 2) association stage, 3) automation "[9]. This is similar to that proposed by Magill that; Stages of motor learning: 1) cognitive stage, 2) associative stage, 3) automatic stage [10].

From the opinions above can be described that to get a skill that can last long required once the process of motor learning. The motor learning process itself must go through the first stages is the cognitive stage, and at this stage the athlete is given information about the movement to be performed, so that the implementation of the motion task begins the acceptance of information and the formation of motor programs. The second stage is the associative stage, ie at this stage the athlete begins to implement what has been reflected in his memory, which is characterized by the more effective ways of performing the task of motion, and he begins to adjust to the skills he performs. here will be seen a coordinated appearance with the progress that occurs gradually, and slow other movements become more consistent. The third stage is the stage of Automation, after the athletes train for some time, it will enter the automatic stage, marked by motor skills that do happen automatically.

\section{B. Dribble Hocking (Dribble)}

In general, dribble is defined as a movement to control the ball that moves with maximum speed along the field with the stick. According to Anders and Myers that dribble is the act of running with the ball while keeping the stick close to the ball [1]. Ten and Haridas say that dribble is a way of escorting a moving ball [12]. It is the skill used to break away. So to get a hockey player who has good basic engineering skills, in the execution of the exercise is very necessary to use the stage of exercise in accordance with the stages of motor learning, which begins with cognitive, associative and automation. By going through the stages is expected to master the basic techniques of hockey game can run well with the ball when escorted by the opponent. Dribble the movement of a player while controlling the ball with stick [7].

The ruler of indor hockey make it almost imposibble to dribble through a skilled defender. To beat a skilled defender a player must either pass the ball or create space to dribble by misleading the defender [6]. The hockey sports branch is generally known to have three dribbles namely (1) dribbled (Close Dribble), (2) dribbling off (Losse Dribble), and (3) 
Indian dribble dribbling [6]. Thus to be able to carry out the dribbling skills of the Indian way in accordance with the demands of modern hockey games today, each player needs the support of adequate physical abilities such as speed playing the ball to the right and left, endurance, hand strength, stamina , and agility move. Because it suits the purpose of dribbling which, among other things, is to attack the opponent's defense area, to be able to control the ball as long as possible in his team, and to keep the ball and the opponent away, the player must be able to move swiftly to play the ball to dodge and deceive the opponent in order to attack to the opposing game area or to survive.

\section{Technical Exercise Method}

The training method is a lesson for developing practice, where the word method is used for the material conditions of activity "[6]. Bompa states that exercise is a way to achieve the goal of improving the organism's system and its function to optimize the performance or appearance of the sport [3]. The MoNE further states that good and successful practice is done regularly, thoroughly, systematically, and continuously / continuously; throughout the year, with an ever-increasing and gradual training load every year [2]. "Technique training is aimed to be able to (learn hard) movement techniques, such as: kick ball technique, servise, fast track, long jump, etc" [8]. In words we can make it clear that regular and sustained exercise will make a movement technique trained to be an automatic movement. In learning motor / learning / exercises didefinisika is to perform skills. And the exercise should be more than ever and consistent. The skills of motion controlled must be permanent anyway, so that whenever such skills are required automatically will occur. So the motion skills performed do not require a hard effort to do so.

From some of the above definitions of methods and exercises we can conclude that the exercise method is a systematic and planned way that serves as atat to present sports activities aimed at the skills of motion or exercise. Various efforts are being made to improve sports skills and maintaining physical fitness. In this regard various approaches taken by trainers or sports teachers in rnemberikan training or lessons to players or students in the field. This understanding of learning strategies is intended as a learning approach when the trainer teaches dribbling techniques in hockey. Based on this, the approach is defined as a form of business undertaken by the trainer in providing learning or training to players or their students with the goal of training results can be achieved optimally. In an effort to improve the optimal performance of a hockey sport should be a player through the process of learning, coaching and regular training. Learning or training is also not a temporary or incidental activity, because irregular exercise will be less meaningful to an increase in the performance of a sport.

\section{Drill Approach}

A drill approach is given to train the game focused on mastery of basic engineering skills. This approach emphasizes the achievement of the goal of the player to master the basic techniques of hockey game. This drill method has been acknowledged by many trainers, since the drill approach method can improve skills techniques rather than athletes. As the word drill in Big Indonesian Dictionary is, do the exercises in a short time. Furthermore it is stated that drill is a train (skill, dexterity etc.) takes time [5]. and besides that which is also required in this method is a coach who really has good motion techniques as well. With the mastery of good motion techniques, the trainers will easily provide a good and correct example.

With this drill method the trainer will be able to have the opportunity to train with a sufficient number of athletes at the same time. This drill approach is an exercise method designed as an exercise to improve a person's skills by assigning to his athlete to do the exercises over and over again. With this expenditure is expected to be a skill and physical improvement of the athletes trained. As suggested by Coker that the drill method very effective to achieve the goal of an exercise [4]. And furthermore it is said that in order to maximize the time available, the drill must activate all learners. From these statements we can conclude that the drill method is an appropriate method to be used in the Dribllehoki exercise. And it is also advisable for the trainer to be able to carry out the time by including all athletes in the training process if the exercise wants to be more efficient.

In addition, Coker states that theoretically, the drill method will give the athlete the chance to practice some of his newly trained skills, demonstrating the skills he mastered, and motivating his next training plan [4]. Clearly already what is said by the Coker, that with drill methods of engineering constraints will be faster obtained [4]. With drill is done continuously is expected to get an automatic movement in which the movement made can not be interfered again from other task done simultaneously. Drill approach itself can be used to train all kinds of sports, because the basic motion of a sport should be trained repeatedly in order to get good movement and correct and make the technique into an automatic movement, automatic movement will reduce the workload of the athlete itself. Thus the appearance of the athletes in a game will be confident and better too.

\section{E. Tactical Approach}

Skills to demonstrate the ability to process the ball, the performance of a truly full effort with struggle, dynamic movement, and the creation of a beautiful goal, accompanied by tactical surprises, which make the audience amazed to see it, is a distinctive attraction from a hockey game. With these skills, players are required to play as well as possible in a match. In a hockey game, the skills that each player possesses are inseparable from a single team and are not used individually. In other words, the ability of a player, will not be able to achieve goals when playing alone and at will regardless of the needs of the team. Because of that many we meet, a player who mimiliki good skills and talents sometimes not played by the coach because the player can not cooperate with a friend in a match.

With a tactical approach to practice there will be an exercise process that prioritizes teamwork, because in this tactical approach is a game that is shown to train the technical play that is adjusted to the exercise / learning of the player or 
the students play with the spirit. The purpose of tactical approach in learning / practice by tomoliyus is to increase understanding of the students about the concept of play through the application of techniques that match the problem or situation in the game [13]. Furthermore it is said: in the tactical approach students are placed in play situations that emphasize on retaining possession of the ball before identifying passing, dribbling or firing exercises [13]. From the above opinion we can conclude that the method of tactical approach exercise is a method of training approach that is designed to train techniques and tactics simultaneously. Because with this tactical exercise approach, the players / students are given the practice as in the actual game, but the game has gone through a modified process. The formulation of the problem in this research are: 1) Is there any difference between technique training method with tactical approach with technique drill method with drill approach to the improvement of basic technique skills of hockey dribbling? This study aims to determine: 1) the difference between the technique technique method using the drill approach with the technique training method using a tactical approach to basic hockey engineering skills.

\section{MATERIAL AND METHOD}

The method used in this study is experimental, where in the experimental class students are given the method of tactical exercise and the control class is given drill practice method. Furthermore, both classes are given basic technical skills test hockey. And analisys in use is the F test. F test known as concurrent Test or test Models/Test Anova, i.e. test to see how the influence of all free variables together against the variables bound.

\section{RESULTS AND DISCUSSION}

The difference in the effects of exercise methods with tactical approaches an alternative hypothesis of basic engineering skills of hockey (Ha) that States that the ability of the different techniques of hockey dribbling between groups of students who learn with a tactical method of drill and the drill received, the value of Fhitung is 9,407 $>$ Ftabel $=8.53$. If $F$ calculate > from table $\mathrm{F}$, (starting in $\mathrm{Ho} \mathrm{Ha}$ received) so significant or model can be seen in the columns on the Anova significance (Processed with SPSS, use regression test with Method Enter/Full Model). Significant model for column of significance $(\%)<$ Alpha). means accepting the ha refused to ho, so that it can be concluded that there is a significant difference between the drill approaches hokey dribbling skills and tactical approach. This means that the ability of the technique to learn hockey dribbling by using higher tactical methods of the students who learn the drill.

For tactical method column and price drill Ftabel is searched based on $\mathrm{dk}$ between columns (numerator $=1$ ) $\mathrm{dk}$ in denominator 16 is (3.63). Price F arithmetic > F table then ho rejected and accept $\mathrm{Ha}$. This means that there is a difference in dribbles ability based on training methods. Tactical exercise methods improve dribling skills.

Differences Effect of Exercise Methods With A Tactical Approach to Drill Approaches to Basic Techniques of Hockey Skills. Sport is not only aimed at achieving without a fun process for students. Students need the support of a fun workout environment, cooperation with a fun companion or practice with an exercise setting where students feel they are playing.

On the other hand one of the important aspects that determine the outcome of the exercise that is achievement motivation is dynamic. Required training methods that can provide pleasure for students. One method that can provide pleasure while providing opportunities for students to master dribling techniques is a tactical method. The method can provide fun, break fun with activities and help make quick and precise decisions on the game.

On the other hand, dribbling exercise using a tactical approach loaded with tasks given can stimulate thinking because the game is done really. The students learn to decide and can judge how the movement and appearance in the field. The tactical approach seeks to relate tactical play skills and basic engineering skills by emphasizing the selection of ambient settings that can enhance students' achievement motivation.

\section{CONCLUSION}

Tactical method is better than the drill method of dribbling hockey learning result. because there is a significant difference. The tactical method contains students feeling happy and the condition makes students more intense, directed to the goal of exercise, have endurance and able to maintain balance during practice. The tactical approach itself is more directed to the game, so the athlete or student is directed to the real-life situation where the students play but still earnestly to achieve the outcome of the practice, For the extracurricular activity trainer, the result of this research can be a description of the development in providing tactical and drill methods both in teaching and learning process and training. For the School; Schools need to provide trainers who are competent in their fields and have the ability to improve student achievement exercises.MS Word Formatting toolbar.

\section{REFERENCES}

[1] Anders, Elizabeth dan Sue Myers.Field Hockey: Step to Success. Champaign: Human Kinetics, 1999. 188

[2] Anonim. Pedoman dan Modul Pelatihan Kesehatan Olahraga Bagi Pelatih Olahragawan Pelajar. Jakarta: Depdiknas, PPKJ, 2000.

[3] Bompa, Tudor O. Theory and Metodology of Training. Dubuque: Kendall/Hunt Publshing Company, 1999.

[4] Coker, Cheryl A. Motor Learning and Control for Practitioners.Mexico :McGraw Hill, 2014.

[5] Depdiknas. Kamus Bahasa Indonesia. Jakarta: Balai Pustaka, 2008.

[6] Glencross, D. J. Coaching Hockey:The Australian Way. South Melbroune: Australian Hockey Association,1984.

[7] Hockey in Australia, "Hockey Word", 2006.

[8] James Tangkudung, Kepelatihan Olahraga, Pembinaan Prestasi Olahraga, Jakarta: Cerdas Jaya, 2012

[9] Rahayu, Ega Trisna. StrategiPembelajaranPendidikanJasmani. Bandung: Alfabeta, 2013.

[10] Richard, Magill A. Motor Learning and Control. New York University, 2011. 
[11] Sardiman. Interaksi dan Motivasi Belajar Mengajar. Jakarta: RajawaliPers, 2014.

[12] Ten, Helen dan M. P. Haridas.Hoki. Selangor DarulEhsan: FajarBaktiSdn. Bhd, 2006.
[13] Tomoliyus. Pendekatan Keterampilan Taktis dalam Pembelajaran Bola Basket. Jakarta: Depdiknas, 2001. 